\title{
The Implementation of History Learning Through the Values of Indis Architecture of Kapitan House to Enhance Students' Social Solidarity
}

\author{
Eva Febriani"; Nunuk Suryani; Sariyatun \\ Department of Teaching and Training Education, Sebelas Maret University, Indonesia \\ Email: evafebriani672@yahoo.com
}

http://dx.doi.org/10.18415/ijmmu.v5i2.115

\begin{abstract}
In the educational field, the implementation of History learning that provides local culture heritage is defined as a small starting point for the character changes of a large generation of notion. In the context of cultural values, several values such as acculturation, tolerance, cooperation and mutual cooperation are presented through the Indis architecture of Kapitan house as a model of History learning that is relevant to assist the growth process of a generation having characteramong the plural society. In this study, researchers propose the Indis architecture values of Kapitan house to transform the values of local culture heritage as a form of students' solidarity. Through the existing values on Indis architecture of Kapitan house, the students are expected tobuild the tolerance, mutual cooperation, cooperation and mutual respect in diversity. In order to investigate the purpose this study, mixed-method research that was meant as the combination between quantitative and qualitative research was applied in SMAN 8 Palembang. To clarify, this study aimed at presenting the locality of Palembang history in forming the students' social solidarity.
\end{abstract}

Keywords: Learning implementation; Kapitan house; Social solidarity

\section{Introduction}

The issues of community who do not care about cultural diversity in social life lead many times to prolonged conflict. According to Taquiri in Newstorm and Davis (1977), conflict is a social life legacy that may be applicable under several conditionsbrought about by the rise of disagreements, controversy and contradiction between two or more parties continually. Within the scope of universal social life, conflict or social problems arise due to the inability of society to manage the diversity of ethnic groups and each individual has different views. The problems usually arise in the context of ethnic, cultural, religious and racial symbols. This is possibly happened due to a lack of people's understanding of social integration among the plural society. The problems not only appear in society, but also grow in the educational context, school in particular that should be a placeto develop the creativity and imagination in order to form the character of next generation of the nation. In fact, this gets less attention that leads a gang fight often being hold among students, less respect to the teachers, mocking friends, and verbal and physical bullying. 
The underlying solution to avoid increasing numbers of conflicts and social problems that occur on young people in community life especially in the school environment is starting from the role of education. This means education must focus on investing social values to learners, as the provisions in facing the complex conflict that occurred in contemporary society. In addition, the role of education must be able to develop Indonesian multicultural society, leading to the socialist, dynamic, pluralistic, tolerant, patriotic and democratic society.

Social solidarity values in learning can be delivered through history learning that is presented through the form of local cultural heritage. Learning of values in the local cultural heritage can increasestudents' character. According to Sariyatun (2013) in the values of "local wisdom" requires a strategic function to build character and identity of the nation. Djuwita (2009) also adds that it is considerably effective if a learning that aims to find the values of life can help learners to explore the existing values in society, whether it is in the form of self-value or cultural values. Then, the process is conducted through critical thinking so that students have the ability to improve the quality of thought and feelings. This education of value approach involves at least four dimensions, ranging from the identification of core valuesfor personal, social, and religious, the philosophical and rational discovery of core values, affective or emotive responses toward those core values, and also decisions making relating to core values and responses of a person.

In shaping students' social solidarity attitude through the implementation of History learning, the researcher chooses the approach of values education through Values Clarification approach or VCT because it is considered as the proper methodin learning process for the learners in finding and determining a value that can be absorbed to shapelearners' solidarity social life. The social solidarity of learners will be presented by the values of Indis architecture which is an example to reflect a cultured society but a unity in the form of a building that is Kapitan house. The values contained in Indis architecture in Kapitan house will be the effective historical learning material, which will be able to create a national character education so that it shapes citizen who understand the character and social harmonization in pluralist society. Concerning to the values contained in Indis architecture found in Kapitan house, learners are invited to interpret the construction of the building that means the values of life such as acculturation, culture, cooperation, mutual cooperation and tolerance in social life are the legacy of ancestors who have attached to the community especially in Palembang. This becomes the main duty for future generations to be more understood about the differences occur among multicultural society that do not cause negative attitude and lack of sensitivity to the social life of the school and community. The shaping of social solidarity values of learners is given in integrative way in History lesson. Accordingly, it is important for the researchers to present an effective History lessons through the implementation of values of Indis architecture in Kapitan house by using the approach of values-investing through VCT (Value Clarification Technique) learning.

\section{Methodology}

This learning implementation research was in the form of History learning model that used a combination qualitative and quantitative researchcalled mixed-method. According to Sugiyono (2015: 21), mixed-method is a research that combines quantitative and qualitative methods to usetogether in a research activity in order to obtain the data more comprehensive, valid, reliable and objective.

In this research, the first step to collect the data was qualitatively gained through observation, interview and literature study. By all means, the detailed explanations of that stage are: (1) researcher conducted interviews with teachers and learners to determine the level of social solidarity attitude; (2) researcher observedthe process of History learning and the usage of media; and (3) researcher analyzed 
the document conducted on learning tools or learning devices used by teachers. After the qualitative data had been obtained, those would be analyzed and used as the basis of formulating hypothesis.

Furthermore, quantitative stage was conducted to test the hypotheses in which the researcher used two classes as the object of research. One class was used as a control class while the other was as an experimental class. Subjects of this study were students in class XI which each class involved 30 students. This study gave treatment between experimental class (XI IPA 3) and control class (XI IPA 5). In the quantitative phase, the t-test formula was used to analyze the data which was comparing the results between the experimental class using the implementation of History learning through the values of Indis architecture in Kapital house and the control class that used the lecturing and discussion as learning model. In addition, quantitative analysis used instruments that the reliability had been validated and tested. Briefly, this research conducted at SMA Negeri 8 Palembang aimed to increase the students' social solidarity by using the results of the effectiveness test known through the pre-test and post-test of the experimental class compared with the pre-test and post-test of the control class.

\section{Findings and Discussion}

\subsection{The Values of Indis Architecture of Kapitan House}

Value is derived from the Latin vale're which means to be useful, empowered, applicable, likable, desirable, pursued, respectable, and leads people who comprehend it being dignified so that the value is defined as something considerably good, beneficial and rightfor one's or people's belief (Adisusilo., 2014: 56). While architecture refers to a form of art, but has a little difference in meaning, that is the architecture uses art as valuable thing to use as interior of building (Kaliesh., 2014: 87).

The variety of the building interior in Nusantara, also called the Archipelago for another term of Indonesia, enacts the architecture being rich of disparity in the style of building. This is generally causedby the interior features of buildings, shapes of buildings, concepts belong to buildings and the most importantly is in what year the building was built because the types of architectural styles will be qualified according to the period. Indis architectural style for example, this architecture developed in the Archipelago country during the Dutch colonial period. According to Soekiman (2000), Indis comes from the Nederlandsch Indie or Dutch East Indies term in Indonesian which means as the name of a colony of the Dutch Government in the Far East, or often also called NederlandschOost Indie.

The results of Dutch culture in the form of Indis architecture spread to some areas in the Archipelago as in Palembang with Indis architecture in the form "Kapitan house". Essentially, Indis is defined asa blended cultures between Dutch and local culture. On the other side, something becomes of the attraction of Kapitan house is the presence of elements of Chinese culture as the representation of Kapitan house ownership. It is called the Kapitan house because it belongs to a Chinese leader who was appointed by the Dutch colony government and was given the rank of a Kapitan that has same position as Captain. Kapitan serves as a representative and an intermediary between the colonial rulers and Chinese community in village (Gin., 2004: 711). Further, Adiyanto (2006: 14) added that the task of a Kapitan given to Chinese descendants is to safeguard the security of the region and the trade of opium. Those three culture elements to be a foundation in explicit knowledge definitely have multicultural additive process. Culture of the colony (Dutch) adapted to the local building style (Palembang) and adapted to who belongs to the house (Tionghoa). In that case, the author explained generally on how the form ofarchitecture of those three cultural elements that create Indis culture in the form of the Kapitan house.

First, Chinese architecture has a featurein the form of courtyard, opened-architectural elements, and the use of distinctive colors and construction of wood (Kaliesh: 2014: 89). Second, the Dutch architecture (modern European) is in the form of shield roof, non-terraced building, memorable 
monument, high wall pillars, large andtall windows, and very wide yard. Those features were adapted to the first appearing of Kapitan house at the beginning of the 19th century, which is meant in the category of Indsiche Empire Style. Indsiche Empire Style is a style of neo-classical architecture that spread on the parts of Europe in which the form of the adaptation build a colonial style that is adapted to the environment, climate and local materials in the Archipelago. Indsiche Empire Style is then influenced by the type of landhuis architecture that developed in the early 18th century and 19th century (Mulyono, 2011: 26). The third is the local architecture in Palembang (South Sumatra), which is usually associated with the limas house, rakit houses, ware house, meeting houses and worship house as a physical form of traditional houses in Palembang. The most attracting traditional architecture of Palembang is the limas house. The roof shape of limas is the most common roof used by people in Palembang until recently (Alimansyur et al., 1985: 67).

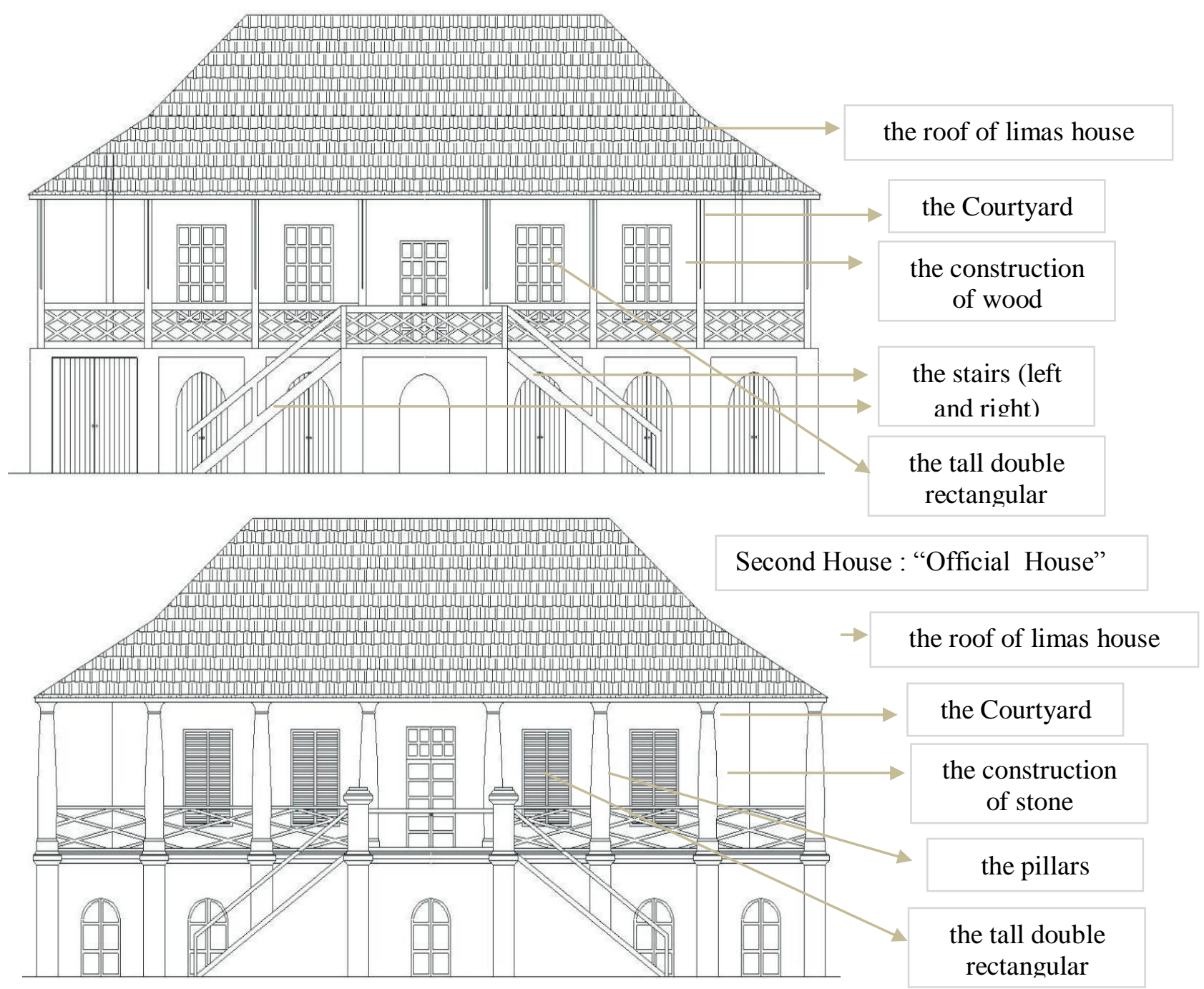

Fig. 1 Two core buildings of Kapitan house, Adapted ilustrastion by researcher 
Mulyadi (2017), the 13th descendant of Kapitan Tjoa Ham Hin who keeps his ancestral heritage, according to his parents many times ago there were about 15 Chinese traditional houses left in the Kapiten area. Each house was circularly built facing a field or room that is intentionally open. But the heritages are now left only two core buildings because others are destroyed eroded time which the first house is called as a residence and the second house is as the ash house. Both houses are still closely related to elements of culture of local, Europe and China (Febriani., 2015). Physically, these three cultures are covered through the values of Indis architecture having a philosophical meaning in everyday life. The art of Indis house is implied by the values of acculturation, culture, cooperation, mutual cooperation, responsibility and tolerance. These values can be used as a reference in daily life within society locally and globally. Figure 1 is general elaboration of the form of Indis house with the expectation that there should be no disconnection of the values of every symbol and meaning of the building.

\section{The Roof of Limas House}

Both the first building called a residence house or abu house and the second building called the official House have a roof called Limas. The name of limas comes from the form of roof is rectangular (Alimansyur., 1985: 16). The limas roof that functioned as the protector of Kapitan house determines the existence of viscosity of traditional roof of Palembang culture that can acculturate well.

\section{The Construction of Wood and Stone}

The woods are the main construction of local and Chinese buildings while the stonesare the main construction of European or Dutch buildings (second house). The construction of stone and wood in Kapitan house building both on the surface of floor and wall is the creation of three cultural elements that coexist into one, so that the philosophycreated in this building is the values of cooperation, mutual cooperation, toleranceto reach a high solidarity in a house that we can certainly be comprehended in everyday social life.

\section{The Stairs (Left and Right)}

According to Alimansyur (1985: 17), the stairs in the local buildings are commonly amounted to odd due to the philosophy which means the home keeper will easily get the blessing of life. Yet, from the survey it is found that in each Kapitan house have eight steps on the left and the right side which means that the number of stairs is even. It could be concluded that there is a possibility that the stairs are truly amounted to odd but it is long-buried due to the restoration of the front yard of Kapitan house.

Furthermore, there are differences in the unity of this building in which the stairs in the second Kapitan house made of stone materials, while the first building was made from the wood. The left and right side on the front display of Kapitan house represents the traditional building of Palembang.

\section{The Pillars}

Pillar is a stanchion of buildings in a house that have other additional functions and various forms that are fitted to the benefits and cultural style. In the first Kapitan house is a pillar made of wooden that its form represents the features of local tradition. The pillars in the second Kapitan house are large beams that represent the features of traditional European buildings. Although the shape and function of the pillars are different but still does not exclude the local culture that becomes the features of both buildings. 


\section{The Courtyard}

Courtyard is an opened-space on traditional Chinese building. This space is more privately combined with a garden or garden. Courtyard is functioned to let natural light passes during the day or as ventilation (Hadinoto., 2008: 3). Each Kapitan house has a courtyard as an opened-space. Each house is circularly built facing a yard or room that is intentionally opened, according to the ancestors this room function as air conditioner and entrance space of light (Febriani., 2015).

\section{The Tall Doubled-Rectangular Window}

The tall and lined-windows, and double-rectangular windows that resemble the shape of the butter fly are a typology of European (Dutch) architecture in the first and second Kapitan houses. On the other hand, mainly windows in the ash or first house colored in red which is a specific element of Chinese building. Red in this window has a symbolic meaning; according to Chinese belief red symbolizes the color of fire and blood, which is associated with prosperity and fortune. Red is also a symbol of virtue, truth and sincerity, as well as the positive thing (Hadinoto., 2008: 5). In this case, the meaning of the tall red window at Kapitan house is a form of cultural value that represents cooperation and tolerance values.

The researcher summarized the glory of Kapitan house architecture as a symbol of cultural acculturation and a combination of life styles to produce the values of social solidarity through the values reflected in Kapitan house. The values of solidarity that can be applied from the values of Indis architecture of Kapitan house are:

\section{a. The Values of Acculturation}

The combination of local culture, Chinese and Dutch will never happen if they do not accept the cultural differences of immigrants. In other words, the additive process of those three cultures runs well which results in acculturation value as a new process of cultural combination that does not eliminate the local culture.

\section{b. The Values of Culture}

Cultural values contained in Kapitan house are not only one element. Those could be local culture that emphasizes Limas as a form of local traditional house, Chinese culture that favor the use of a typical red interior, and Dutch that adorn the pillars of the house. These three cultural elements become a force in the form of residential and official houses.

\section{c. The Values Cooperation and Mutual Cooperation}

In the construction process Kapitan house is done in cooperatively by local residents and the Chinese workers which is authorized by the Dutch who helped the process of building the Kapitan house.

\section{d. The Values of Tolerance}

Since the past, Palembang people have attitude to always being able to receive and interact in good manner with the migrant people whose aims to trade as well as with those who choose to settle. In 
social and cultural life, there is hardly any conflict between the local and the migrants except with the immigrants who aimed at colonizing and seizing the local authority. Both the local and migrants mutually respect each other and accept the different ethnic, religious and culture.

Through History learning presented in the form of Indis architectural values of Kapitan house becomes a reflection for learners to reflect themselves in order to have a high social solidarity attitude so that can minimize the growth rate of social conflicts that occur in the education field and society. Social solidarity attitudes shaped in the form of the similarities inthe opinion difference, mutual cooperation in school activities, cooperation to create the comfort and orderliness in school and tolerate in religion aspect becomes a valuable reflection of the values for every student.

\subsection{Social Solidarity}

According to Johnson (1986: 181), social solidarity is a relationship between the individuals or groups based on the moral feelings and beliefs reinforced by shared emotional experiences. This understanding is further clarified by Durkheim in Soedijati (1995: 25), "solidarity is the trustworthiness feeling among the members in a group or community". If people can trust each other so that they will definitely create a friendship, being respectful, being encouraged to take responsibility and pay attention to others. It can be concluded that social solidarity is a feeling of mutual trust, shared ideals, friendship, and togetherness among individuals as members of the group because of shared emotional and moral feelings. In the perspective of sociology, the close relation between groups of people is not only a tool of gaining or achieving the dreams, but this relation means as main goals of community life. The solidity of relation among the members of group will generate a sense of belongingness among the members.

Relating to the development of society, Durkheim argues that society evolves from classical society to modern society. One of the main components of society that Durkheim concerns in the development of society is its social solidarity. The classical society has different form of social solidarity in modern people. The distinction between mechanical and organic solidarity is one of Durkheim's famous contributions. The purpose is creating the unity and united social individuals in diverse community. This can be associated with the slogan of the Indonesian that is Bhineka Tunggalka.

In shaping social solidarity to lead people, especially the young generation to understand the meaning of unity, cooperation and mutual cooperation can begin by shaping the character of young generation in the school. Why should be in school, because school is a miniature of community or a model of social systems in which students must interact with the people at school according to certain roles. More explanation about education and cultural understanding in the main function of education is to transmit the values and norms in society. Schools in this case have the duty to embed the values generally to students. These valuable values must be learned by individuals to live and accept in society. Thus, learning about embedding the values of social solidarity is considerably critical for shaping the better character of young generation.

\subsection{The Implementation of History Learning Through the Values of Indis Architecture in Kapitan House}

The researcher tested the implementation of product development with model implementation test conducted in class XI IPA 3 as experimental class and XI IPA 5 as control class in SMA Negeri 8 Palembang. Implementation of History learning through the values of Indis architecture in Kapitan house was a combination learning model using scientific approach or Saintific and VCT (Value Clarification Technique), and combined with PBL (Problem Based Learning) model. In scientific approach or 
Saintific, there were three stages of learning, namely; 1) the introductory stage, (2) the core stage (observing, asking, reasoning, trying, creating a network), and (3) closing stage. Further, on the VCT approach (Value Clarification Technique) there were also three stages of learning: (1) choosing, (2) respecting, and (3) doing. While in the model of PBL (Problem Based Learning) learning, there are five steps of learning: (1) student orientation to the problem, (2) organizing for learning, (3) guiding the investigation, (4) presenting and developing the work, (5) evaluating and analyzing.

In the implementation phase of learning, the material used was the cultural impact of European colonization (Dutch) for the Indonesian, especially in the area of Palembang. The following were the explanations of the implementationstages:

\section{The First Phase Used Phase 1 of Scientific Approach (Introduction) and Phase 1 of the PBL (Orientation)}

The teacher greeted and prepared students psychologically and physically to follow the learning process by praying, asking students' attendance, class cleanliness and neatness. Subsequently, teacher conveyed apperception by asking the students about the arrival of Europeans to Indonesia. Furthermore, the teacher conveyed the purpose of learning and competence must be mastered by students through Power Point. It aimed to orientate learners about the problem.

\section{The Second Phase Used Phase 2 of Scientific (Observing and Questioning)}

Teacher displayed a video about the first existance of Chinese settlement that is Kapitan village in Palembang in which the students were assigned to observe it. Then the students were assigned to write one question relating to the material on a paper (the card given by teacher) and then the questions were collected (collected question became a topic for discussion activity). Students' questions were selected according to the learning objectives to be achieved.

The Third Stage Used Phase 2 of the PBL (Organizing), Phase 2 of the Saintific (Questioning and Reasoning), Phases 1 and 2 of VCT (Choosing, Rewarding) and Phase 2 of the Saintific (Trying), and Phase 3 of the PBL (Guiding Individual and Groups Investigations)

Teachers dividedstudents into 5 groups and directed them to gather with their group members. Then the teacher distributed hand out contained material that will be the source of discussion topics. Furthermore, the teacher commanded the students to ask if they faced some difficulties and helped students to reason the material, and then students had to determine the values of social solidarity found on their exploration about Indis architecture of Chinese house in Palembang and comprehend the values (each group was required to comprehend at least one value). After that, each group confirmed the architectural value selected by the group with teacher guidance. Teachers assigned each group to discuss with their groups. It was continued by encouraging students to appreciate the opinions of other members of groups. And the last, teachers encouraged students to seek additional information from other sources outside of group discussions and to conduct investigation to find and formulate answers using textbooks, the internet, and other relevant books. 


\section{The Fourth Stage Used Phase 4 of the PBL (Presenting and Developing the Work) and Phase 2 of Saintific (Creating a Network)}

Teacher assigned students to present their work through presentation which had seven minutes of explanation for each group 7. Then teacher directed and gave the reinforcement of discussion about the comprehension of the solidarity values on Indis building which continued by responding and giving feedback among the groups.

\section{The Fifth Stage Used Phase 5 of the PBL (Analyzing and Evaluating the Problem-Solving Process) and Phase 3 of the VCT (Doing)}

The teacher analyzed and evaluated the discussion activity and the problem solving. Then teacher directed the students to comprehend the solidarity values they chose in Indis building of Kapitan house in Palembang. Ultimately, teacher asked students to make the report and would be gathered at next meeting.

\section{The Sixth Phase Used Phase 3 of the Saintific (Closing)}

Students were given a short review of the results of learning activities. Then students and teacher drew conclusion of material that had been discussed. Furthermore, teacher providedthe reinforcement to studentsin comprehending the values of solidarity in Indis architecture of Kapitan house in Palembang. The teacher evaluated the learning to measure the achievement of learning objectives and finally the teacher ended the subject with partings.

\subsection{The Effectiveness of History Learning Through the Values of Indis Architecture in Kapitan House}

The effectiveness of History learning through the values of Indis architecture of Kapitan house was done through the comparison of pre-test and post-test of control class and experiment class. The effective or ineffective test of this learning model was done in class XI IPA 3 as the experimental class and class XI IPA 5 as the control class in SMA Negeri 8 Palembang. The form of test given was in the form of cognitive and affective questions that was associated with the indicators of students' social solidarity. The results of effectiveness test of students were calculated using SPSS 21 application with the initial step to do homogeneity test. Thistest was searched to find out whether the experimental class and the control class came from the equal or unequal variant.

Based on the results of the research, effectiveness test had been calculated through two stages in which the first test was to test the effectiveness of learning outcomes and the second stage was to test the effectiveness of students' social solidarity. Before conducting independent t-test, the data should be normally distributed and homogeneous. From t-test calculation, the mean of post-test on class achievement of experimental class is 61,17 , while mean of post-test of control class is 55,83. From ttestcalculation, the obtained result 2,1475 with significance level $0,16(0,016>0,05)$, hence Ho is rejected which means there is difference of attitude mean between experiment class and control class. In the effectiveness of attitude test, the mean of post-test was 107,13 in experiment class and 103,13 in control class. Further, the t-test obtained 4.238 with significance level of $0.000>0.05$. Due to the significance level of t-test was smaller than 0.05 , it could be concluded that HI is accepted, which means that both classes have significant differences both of their learning ability and social solidarity attitude. 
Based on the obtained data, there is a positive and significant improvement in the experimental class that used the application of History learning through the values of Kapitan house with the PBL (Problem Based Learning) learning model, the Saintific approach and the VCT (Value Clarification Technique). The summarized result is that the implemented learning model has the effectiveness to increase students' social solidarity.

\section{Conclusion}

The implementation of History learning through the values of Indis architecture of Kapitan house aims to shape the students' social solidarity attitudeto lead the young generation growand can develop the attitude of kindness, tolerance, unity, cooperation, sympathy and mutual cooperation among the plural society. History learning about the values of Indis architecture of Kapitan house is packed into learning model of affective History learning with the Saintific approach and VCT approach (Value Clarification Tehnique) and then combined with the PBL model (Problem based learning). The results of the implementation and effectiveness contains the differences in the improvement on experimental class that is XI IPA 3 using History learning model through the values of Indis architecture of Kapitan house with Saintific approach and VCT and then are added with PBL model in its application. Furthermore, the control class that is class XI IPA 5, does not use the learning model and only use the lecture method.

The results obtained after being given treatment are the two classes have different levels of social solidarity attitudes. Classes that use History learning model through Indis architecture values of Kapitan house have a high degree of solidarity ability compared to classes that model of learning does not implement. This learning model was proved effectively to apply to students of class XI IPA 3 in SMA Negeri 8 Palembang with increasing students' social solidarity and students' result.

\section{References}

Adisusilo, Sutarjo. (2014). Pembelajaran Nilai-Karakter: Konstruktivisme dan VCT sebagai Inovasi Pendekatan Pembelajaan Afektif. Jakarta: Rajawali Pers.

Adiyanto, Johannes. (2006). “Kampung Kapitan Interpretasi 'JeJak' Perkembangan Permukiman dan Elemen Arsitektural”. Dimensi Teknik Arsitektur, (34)1.

Alimansyur, dkk. (1983). Sejarah Perlawanan Terhadap Imperialisme dan Kolonialisme di Daerah Sumatera Selatan. Jakarta: Depdikbud.

Djuwita, Puspa. (2009). Peningkatan Kemampuan Guru dalam Pembelajaran PKN dengan Pendekatan Pendidikan Nilai yang Inovatif. Jurnal Kependidikan TRIADIK, 12(1).

Febriani, Eva. (2014). "Perkembangan Permukiman masyarakat Tionghoa di palembang Pasca Kesultanan palembang (1823-1942)”. Palembang: Universitas Sriwijaya.

Handinoto. (2008). Perkembangan Bangunan Etns Tionghoa di Indonesia (Akhir Abad ke-19 sampai 1960-an). (Prosiding Simposium Nasional Arsitektur Vernkular 2. Surabaya: Petra Cristian University.

Johnson, Doyle Paul. (1986). Teori Sosiologi: Klasik dan Modern, Jilid 1, Diindonesikan Oleh; Robert M.Z. Lawang, Jakarta: PT Gramedia. 
Kaliesh, Hamdil. (2014). Arsitektur Tradisional Tionghoa: Tinjauan Terhadap Identitas, Karakter Budaya, dan Eksistensinya, dalam Jurnal Teknik Arsitektur. Pontianak: Universitas Tanjung Pura, 1(1).

Mulyono, dkk. (2011). "Perwujudan Budaya Indis Pada Interior Gereja Krosten Jawi Wetan Mojowarno", Dimensi Interior, 9(1).

Sariyatun, Sariyatun. (2013). "Pengembangan Model Pembelajaran Nilai-Nilai Budaya Di SMP Berbasis Tradisi Seni Batik Klasik Surakarta". Paramita, 23(2).

Sugiyono, Sugiyono. (2015). Model Penelitian \& Pengembangan. Bandung: Alfabet.

Soedijati, Elisabeth, Koes. (1995). Solidaritas dan Masalah Sosial Kelompok Waria. Bandung: UPPM STIE Bandung.

Soekiman, Djoko. (2000). Kebudayaan Indis dan Gaya Hidup Masyarakat Pendukungnya di Jawa (Abad XVIII - Medio Abad XX). Yayasan Bentang Budaya. Yogyakarta.

\section{Informan}

Interview with Mr. Mulyadi. (2017). Kapitan House in Palembang.

\section{Copyrights}

Copyright for this article is retained by the author(s), with first publication rights granted to the journal.

This is an open-access article distributed under the terms and conditions of the Creative Commons Attribution license (http://creativecommons.org/licenses/by/4.0/). 